\title{
Diagnostic and prognostic impact of desmocollins in human lung cancer
}

\author{
Tiantian Cui, ${ }^{1}$ Yuan Chen, ${ }^{1}$ Linlin Yang, ${ }^{1}$ Masoud Mireskandari, ${ }^{1}$ Thomas Knösel, ${ }^{2}$ \\ Oing Zhang, ${ }^{1}$ Lukas Herbert Kohler, ${ }^{1}$ Almut Kunze, ${ }^{3}$ Norbert Presselt, ${ }^{4}$ Iver Petersen ${ }^{1}$
}

\begin{abstract}
- An additional data is
published online only. To view this file please visit the journal online (http://dx.doi.org/ 10.1136/jclinpath-2011200630)

${ }^{1}$ Institute of Pathology, Jena University Hospital, Jena, Germany

${ }^{2}$ Institute of Pathology, LudwigMaximilians-University Munich, Munich, Germany

${ }^{3}$ Pathology Institute at the Central Clinic Bad Berka, Bad Berka, Germany

${ }^{4}$ Thoracic and Vascular Surgery, Central Clinic Bad Berka GmbH, Bad Berka, Germany
\end{abstract}

\section{Correspondence to} Dr Iver Petersen, Institute of Pathology, Jena University Hospital, Friedrich-Schiller-

University Jena,

Ziegelmühlenweg

1, 07743 Jena, Germany; iver.petersen@med.uni-jena.de

TC and YC contributed equally

Accepted 1 August 2012

Published Online First

20 September 2012

\begin{abstract}
Objective Desmosomes are intercellular junctions that confer strong cell-cell adhesion. Two main members of desmosomal cadherins, desmogleins (DSGs) and desmocollins (DSCs), are involved in carcinogenesis. However, their role in human lung cancer remained elusive. The aims of this study were to analyse the expression of DSCs and to evaluate their clinical application in lung cancer.

Methods The expression of DSC1-3 mRNAs was analysed by RT-PCR. The methylation status of DSCs was analysed by demethylation tests and bisulphite sequencing. Protein expression of DSCs in primary lung cancer was evaluated by immunohistochemistry on tissue microarrays.
\end{abstract}

Results DSC1-3 mRNAs were downregulated in lung cancer cells, and the expression was restored in four out of seven cell lines, respectively, after 5-aza-2'deoxycytidine treatment. A heterogeneous methylation pattern was detected by bisulphite sequencing in exon 1 of DSC2 and DSC3. In 199 patients with primary lung cancer, we found that lower protein expression of DSC1 was significantly linked to worse tumour differentiation $(p=0.017)$, DSC3 proteins were more expressed in squamous cell carcinoma (SCC) compared with adenocarcinoma $(A D C)(p<0.001)$, and reduced expression of DSC1 and DSC3 was significantly correlated with poor clinical outcome $(p=0.045$ and $p=0.007$, respectively).

Conclusions Our data suggest that downregulation of DSC1-3 may be explained by DNA methylation, DSC1 may be a marker for tumour differentiation, DSC3 has a potential diagnostic value in subclassification of non-small cell lung carcinoma into SCC and ADC, and furthermore, DSC1 and DSC3 may be prognostic markers for lung cancer.

\section{INTRODUCTION}

The desmosomes are intercellular junctions that act as anchors for intermediate filaments, and they are crucial to tissues that experience mechanical stress. ${ }^{1}$ Desmosomes are made of proteins from three families: the desmosomal cadherins, the armadillo family and the plakin family of cytolinkers. The cell adhesion proteins of the desmosomes, DSGs (DSG1-4) and DSCs (DSC1-3), are members of the cadherin family. ${ }^{2}$ DSGs and DSCs are membrane-spanning glycoproteins that mediate adhesion by interacting with other family members on adjacent cells. ${ }^{3} 4$

The role of desmosomal proteins in cancer development and progression is not well understood, though a body of evidence indicates that they may influence epithelial cell invasion and metastasis since an important function of desmosomes related to cancer is their ability to inhibit cell motility. ${ }^{5}$ For example, loss of expression of desmoplakin, a component of desmosomal plaque proteins, promotes increased local tumour invasion in a mouse model of pancreatic neuroendocrine carcinogenesis; ${ }^{6}$ loss of DSC2 contributes to the growth of colorectal cancer cells by regulating Akt/ $\beta$-catenin signalling. ${ }^{7}$

Both tumour-promoting and tumour-suppressive functions have been assigned to desmosomal proteins. $^{2}$ For instance, DSG2 was found to be overexpressed in skin cancer, ${ }^{8}$ DSG3 was upregulated in head and neck cancer as well as lung cancer. 91011 By contrast, DSC3 ablation increased the incidence of Ras-induced skin tumour in mice, ${ }^{12}$ and furthermore, DSC3 was found to be downregulated in breast and colorectal cancer due to promoter hypermethylation. ${ }^{13} 14$

In a previous study, we performed suppressionsubtractive hybridisation to compare gene expression between normal human bronchial epithelial cells (HBEC) and a lung squamous carcinoma cell line $\mathrm{H} 2170 .^{15}$ Two cDNA libraries were cloned. The clone, HBEC-80 with high similarity to desmocollin 3, was found in the library enriched for the genes which were downregulated in tumour cells. Further investigations revealed that DSC3 plays an important role in lung carcinogenesis (Cui et al. 2012, in press).

In this study we analysed the expression of DSC1-3 in human lung cancer and investigated their clinical relevance.

\section{MATERIALS AND METHODS \\ Cell lines and cell culture}

Human lung carcinoma cell lines, including nonsmall cell lung carcinomas (SCC: H157, H226, $\mathrm{H} 2170$; adenocarcinoma (ADC): H23, H2030, H2228 and H322), and small cell lung carcinomas (SCLCs: SHP77, CPC-N, H82, COLO677, COLO668 and H526) were purchased from the American Type Culture Collection (ATCC, Rockville, Maryland, USA), and from the German Collection of Microorganisms and Cell Culture (DSMZ, Braunschweig, Germany). Cells were grown in RPMI 1640 medium (BIOCHROM AG, Germany) supplemented with $10 \%$ (v/v) foetal bovine serum (FBS), and maintained in a humidified atmosphere with $5 \% \mathrm{CO}_{2}$ at $37^{\circ} \mathrm{C}$. In addition, three ADC cell lines including D51, D54 and D117 were established in our laboratory. They were derived from primary tumours of patients who were operated at the University Hospital Charité. These cells were grown in Leibovitz 15 media supplemented with $10 \%(\mathrm{v} / \mathrm{v})$ FBS and $1 \%(\mathrm{w} / \mathrm{v})$ glutamine. 


\section{RNA extraction and RT-PCR}

Total RNA was extracted from the cells using the Trizol reagent (Invitrogen, Karlsruhe, Germany). One microgram of total RNA was reverse-transcribed into cDNA using a QuantiTect Reverse Transcription Kit (Qiagen, Hilden, Germany).

PCR amplification of DSC1-3 was performed under the following conditions: $94^{\circ} \mathrm{C} 1 \mathrm{~min}, 53^{\circ} \mathrm{C} 30 \mathrm{~s}, 72^{\circ} \mathrm{C} 30 \mathrm{~s}$, for 35 cycles, with initial denaturation at $95^{\circ} \mathrm{C} 15 \mathrm{~min}$, and final elongation at $72^{\circ} \mathrm{C} 7 \mathrm{~min}$. Glyceraldehyde-3-phosphate dehydrogenase was used as control. Primer sequences are shown in supplementary data 1.

\section{Demethylation tests}

For demethylation tests, seven lung cancer cell lines were plated and cultured in $10 \mathrm{~cm}$ dishes. At $50 \%$ confluence, 10, 20 and $25 \mu \mathrm{M}$ of 5-aza-2'-deoxycytidine (DAC) (Sigma Chemical Co, St Louis, MO USA) were added to the medium on days 0 and 2. Cells were harvested on day 4 for total RNA isolation.

\section{Bisulphite sequencing}

Bisulphite-treated DNA was subjected to PCR amplification. Two pairs of primers (supplementary data 1) were designed for amplification of both unmethylated and methylated sequences. Hot-start PCR (Peqlab, Germany) was carried out to amplify the CpG sites of DSC2 and DSC3 with the following conditions: $95^{\circ} \mathrm{C} 15 \mathrm{~min}, 40$ cycles of $95^{\circ} \mathrm{C} 1 \mathrm{~min}, 60^{\circ} \mathrm{C} 45 \mathrm{~s}$ and $72^{\circ} \mathrm{C} 45 \mathrm{~s}$, with a final extension at $72^{\circ} \mathrm{C} 7 \mathrm{~min}$. PCR products were applied for direct sequencing by capillary electrophoresis (LGC, Berlin, Germany).

\section{Immunohistochemistry}

Three hundred and ninety-eight tumour specimens from 199 patients with primary lung cancer were used for the construction of tissue microarrays (TMAs). All the patients were undergoing surgical operation at the department of surgery of the Central Hospital Bad Berka GmbH. No adjuvant radiotherapy or chemotherapy was administered before surgery. The clinicopathologic features of the samples are listed in table 1 according to the WHO/TNM classification of lung cancer. ${ }^{16}$

Table 1 Study cohort

\begin{tabular}{lc}
\hline Clinical parameters & $\begin{array}{c}\text { No. of patients } \\
\text { Total } \mathbf{n}=\mathbf{1 9 9}(\%)\end{array}$ \\
\hline Tumour differentiation (191) & \\
G1 & $79(41.4)$ \\
G2 & $67(35.1)$ \\
G3 & $45(23.5)$ \\
T stage (194) & \\
T1 & $46(23.7)$ \\
T2 & $106(54.6)$ \\
T3 & $27(13.9)$ \\
T4 & $15(7.8)$ \\
N stage (173) & \\
N0 & $92(53.2)$ \\
N1 & $52(30.1)$ \\
N2 & $27(15.6)$ \\
N3 & $2(1.1)$ \\
Histology (199) & \\
SCC & $128(64.3)$ \\
LCLC & $3(1.5)$ \\
ADC & $63(31.7)$ \\
SCLC & $5(2.5)$ \\
\hline
\end{tabular}

ADC, adenocarcinoma; LCLC, large-cell lung carcinoma; SCLC, small-cell lung carcinoma; SCC, squamous cell carcinoma.
TMAs were constructed as previously described. ${ }^{17}$ All cases were reviewed on whole sections stained by standard H\&E and AB-PAS alcian blue-periodic acid schiff by two pathologists ( $M$ Mireskandari and T Knösel). Two tissue cylinders per tumour with a diameter of $0.6 \mathrm{~mm}$ were present in one TMA.

A section from the TMA was dewaxed with xylene and gradually hydrated. Antigen retrieval was performed by treatment in a pressure cooker for $6 \mathrm{~min}$. The primary antibodies used were as follows: polyclonal antidesmocollin 1 antibody (Sigma, USA; 1:100), polyclonal antidesmocollin 2 antibody (Acris, Germany; $1: 800$ ), and monoclonal antidesmocollin 3 antibody (Acris, Germany; 1 : 100). Detection took place according to the manufacturer's instructions (LSAB 2-kits, DAKO, Denmark). All slides were read by two pathologists ( $M$ Mireskandari and $\mathrm{T}$ Knösel). Immunohistochemistry was scored semiquantitatively as negative (less than $5 \%$ cells were stained) and positive (more than $5 \%$ cells were stained).

\section{Statistical analysis}

To compare the protein expression of DSC1-3 with clinicopathologic parameters, $\chi^{2}$ or Fisher's exact test was applied. Kaplan-Meier survival curves were constructed for statistical significance with the logrank tests. Cox proportional hazard analysis was used to quantify the HR of each risk factor, and forward stepwise multivariable analysis was used to identify the prognostic factors. All p values were calculated two-sided. Difference was considered statistically significant when $p$ value was 0.05 or less. The statistical analysis was performed by using the software package SPSS 19.0 (SPSS, Chicago, Illinois, USA).

\section{RESULTS}

\section{mRNA expression of DSCs in lung cancer cell lines}

RT-PCR showed that mRNA of DSC1-3 was expressed in human bronchial epithelial cells. DSC1 was expressed in $\mathrm{H} 23$, $\mathrm{H} 226, \mathrm{H} 2170$ and $\mathrm{H} 322$, but in other cell lines, there was no signal detectable. DSC2 was expressed in most of the cell lines tested, except for two SCLC cell lines CPC-N and COLO677. DSC3 was only expressed in H226, while silenced in other cell lines (figure 1A).

\section{Restoration of DSCs mRNA expression by 5-aza-2'-deoxycytidine (DAC)}

After treatment with different concentrations of the demethylation agent DAC for $96 \mathrm{~h}$, DSCs mRNA expression was restored in four out of seven cell lines for DSC1-3, respectively (figure 1B). In some of the cell lines, the reexpression of DSCs was in a concentration-dependent manner (eg, DSC1 re-expression in SHP77, DSC2 re-expression in H157 and COLO677, as well as DSC3 re-expression in COLO677).

\section{Analysis of DSCs methylation status in lung cancer cell lines}

We evaluated the methylation status of DSC2 DNA in $31 \mathrm{CpG}$ sites and DSC3 DNA in $20 \mathrm{CpG}$ sites (table 2). There was no $\mathrm{CpG}$ island in the promoter region/exon1 of DSC1, therefore, we could not analyse the methylation status of DSC1 in lung cancer cells. We found that DSC2 and DSC3 were highly methylated in four cell lines where restoration of mRNA expression was detected by demethylation tests. As expected, in normal control HBEC, neither DSC2 nor DSC3 DNA was methylated. 
Figure 1 A: DSCs expression analysis in lung cancer cell lines and human bronchial epithelial cells (HBEC). DSCs mRNA expression was analysed by RT-PCR, showing that DSC1-3 was expressed in HBEC. In lung cancer cell lines, DSC1 was found to be expressed in $\mathrm{H} 23, \mathrm{H} 2170, \mathrm{H} 322$, as well as $\mathrm{H} 226$, and DSC3 was merely expressed in $\mathrm{H} 226$. Unlike DSC 1 and DSC3, DSC2 was expressed in the most of the cell lines tested except for CPC-N and COLO677. Glyceraldehyde-3-phosphate dehydrogenase was used as loading control. B: Demethylation tests in lung cancer cell lines. RT-PCR showed that after treatment with different concentrations of deoxycytidine for $96 \mathrm{~h}$, DSCs mRNA expression was heterogeneously upregulated in four out of seven cell lines. * indicates non-small cell lung carcinoma cell lines.

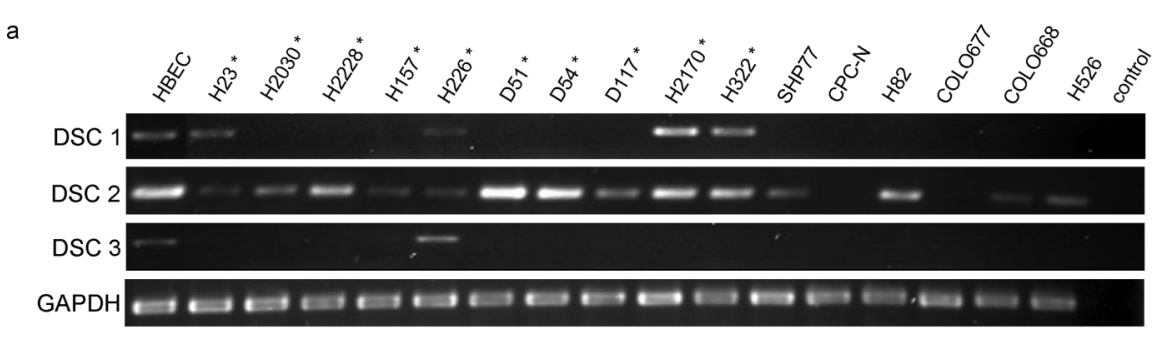

b

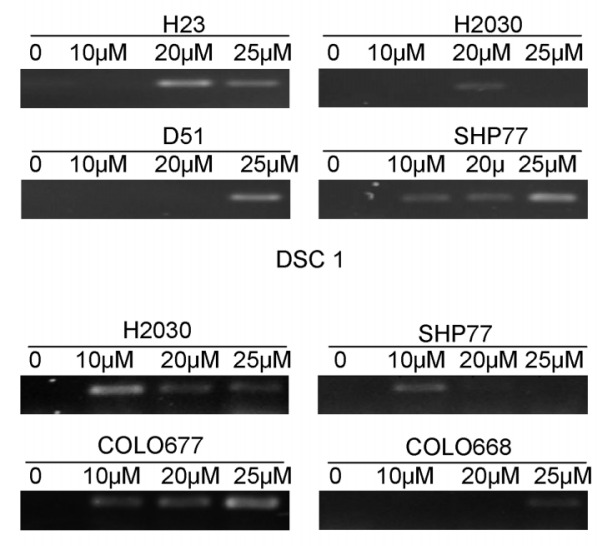

DSC 3

\section{Protein expression of DSCs in primary lung tumours}

Immunohistochemistry showed that DSC1-3 proteins were mainly localised in membrane.

As shown in table 3, 47 cases (23.6\%) exhibited expression of DSC1. A reverse association between DSC1 expression and tumour differentiation was found: high-grade tumours showed significantly decreased expression of DSC1 ( $p=0.017$, table 3$)$. However, the expression of DSC1 did not differ significantly by other clinicopathological parameters. DSC2 and DSC3 were expressed in $68.3 \%$ and $31.7 \%$ of primary lung tumours, respectively. Additionally, DSC3 seemed to be a marker to distinguish SCC from ADC, since SCC showed significantly more positive staining of DSC3 compared with ADC $(p<0.001$, table 3$)$. Examples of DSC1-3 protein expression in primary SCC of lung are shown in figure 2. In bronchial epithelial cells of normal bronchus, DSC1-3 staining was not visible (figure 2E-G).

From follow-up data we found that the median survival time for DSC1, DSC2, DSC3 positive and negative patients were 1158 and 787 days, 948 and 835 days, as well as 1218 and 744 days, respectively. Kaplan-Meier survival analysis revealed that downregulation of DSC1 and DSC3 was significantly linked to shorter overall survival $(p=0.045$ for DSC1; $p=0.007$ for DSC3, figure 3A,C). However, the expression of DSC2 was not correlated with clinical outcome $(p=0.544$, figure $3 B)$.

\section{Cox hazard analyses of lung cancer patient prognosis}

The correlation between DSC1-3 expression and clinical outcome was analysed in a multivariable Cox proportional hazard regression model to discover optimal independent prognostic factors. The results are shown in table 4. DSC1 $(\mathrm{HR}=1.682, \mathrm{p}=0.037)$ and DSC3 $(\mathrm{HR}=2.004, \mathrm{p}=0.004)$ were the optimal independent prognostic factors in the final regression model, but not DSC2 ( $\mathrm{HR}=0.759, \mathrm{p}=0.229)$.

\section{DISCUSSION}

Desmosomes, together with adherens junctions, represent the major adhesive cell junctions of epithelial cells. ${ }^{18}$ Desmosomal components are downregulated in certain types of carcinoma, suggesting their possible role in tumour suppression. ${ }^{19-22}$

In this study, we found that the expression of DSC1-3 was significantly downregulated compared with normal control cells. The molecular mechanism responsible for the altered DSCs expression in lung cancer has not yet been well elucidated. So far, no genetic alterations of DSCs have been found. Except for the detailed description of methylation patterns of DSC3 in breast and colon cancer, ${ }^{13}{ }^{14}$ no epigenetic regulation of DSCs has been reported in any other tumour entities. In our study, demethylation tests of DSCs by using the pharmaceutical agent DAC restored the expression of DSCs in four out of seven lung cancer cell lines. In line with this, methylation was detected in $31 \mathrm{CpG}$ sites and $20 \mathrm{CpG}$ sites of exon 1 in DSC2 and DSC3 respectively. These results suggested that DNA hypermethylation is at least partially responsible for the gene silencing of DSC2 and DSC3 in lung cancer cells.

It has been suggested that desmosomal components may contribute to the differentiation of human endometrial carcinoma. $^{23}$ Besides, Monica et $a l^{24}$ and Tsuta et $a l^{25}$ reported that DSC3 was a marker for poorly differentiated SCC and also for squamous differentiation in undifferentiated large cell lung carcinoma (LCLC). Consistent with these results, we observed that lose of DSC1 expression was associated with poor differentiation in primary lung tumours.

Despite extensive study, there are few clinically useful immunohistochemical markers for lung cancer diagnosis and prognosis. ${ }^{26}$ Late diagnosis is a fundamental obstacle to improving lung cancer outcomes. ${ }^{27-29}$ In our study, we could only divide the primary tumours into two major subgroups of SCC and $\mathrm{ADC}$ for statistical analysis, since the sample size of small cell lung carcinoma (SCLC) and LCLC was too small to be further evaluated. In line with the report from Boelens et $a l^{30}$ we found that DSC1-3 expression was not visible in normal bronchial epithelial cells, indicating that DSC1-3 may be upregulated in primary SCC of lung, and additionally, DSC3 seemed to be a marker to distinguish SCC from ADC, since $45.3 \%$ of 

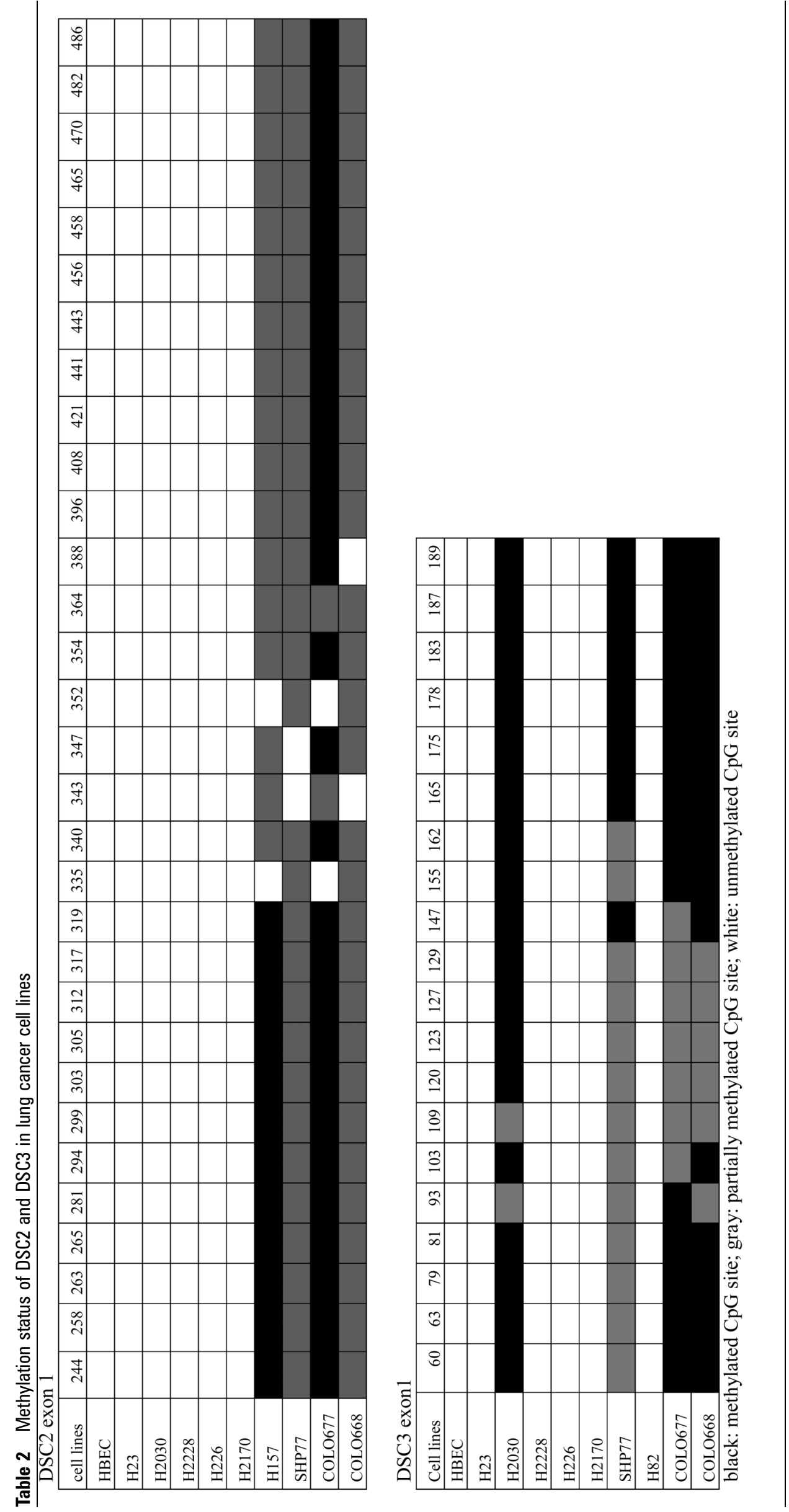
Downloaded from jcp.bmj.com on September 22, 2014 - Published by group.bmj.com

Original article

Table 3 Correlation between DSCs expression and clinicopathologic parameters

\begin{tabular}{|c|c|c|c|c|c|c|c|c|c|}
\hline \multirow[b]{2}{*}{ Clinicopathological parameters } & \multicolumn{2}{|l|}{ DSC1 } & \multirow[b]{2}{*}{ p Value } & \multicolumn{2}{|l|}{ DSC2 } & \multirow[b]{2}{*}{ p Value } & \multicolumn{2}{|l|}{ DSC3 } & \multirow[b]{2}{*}{ p Value } \\
\hline & $(-)$ & $1+1$ & & $(-1$ & $1+1$ & & $(-)$ & $1+1$ & \\
\hline \multicolumn{10}{|l|}{ T stage } \\
\hline $\mathrm{T} 2$ & $86(43.2)$ & $20(10.1)$ & & $36(18.1)$ & $70(35.2)$ & & $72(36.2)$ & $34(17.1)$ & \\
\hline T3 & $23(11.6)$ & $4(2.0)$ & & $10(5.0)$ & $17(8.5)$ & & $15(7.5)$ & $12(6.0)$ & \\
\hline $\mathrm{T} 4$ & $9(4.5)$ & $6(3.0)$ & & $3(1.5)$ & $12(6.0)$ & & $9(4.5)$ & $6(3.0)$ & \\
\hline N1 & $44(22.1)$ & $8(4.0)$ & & $13(6.5)$ & $39(19.6)$ & & $31(15.6)$ & $21(10.6)$ & \\
\hline N2 & $18(9.0)$ & $9(4.5)$ & & $9(4.5)$ & $18(9.0)$ & & $20(10.1)$ & $7(3.5)$ & \\
\hline N3 & $2(1.0)$ & $0(0)$ & & $2(1.0)$ & $0(0)$ & & $2(1.0)$ & $0(0)$ & \\
\hline \multicolumn{10}{|l|}{ Tumor differentiation } \\
\hline G1 & $66(34.6)$ & $13(6.8)$ & 0.017 & $27(14.1)$ & $52(27.2)$ & 0.182 & $47(24.6)$ & $32(16.8)$ & 0.086 \\
\hline G2 & $51(26.7)$ & $16(8.4)$ & & $21(11.0)$ & $46(24.1)$ & & $48(25.1)$ & $19(9.9)$ & \\
\hline
\end{tabular}

Note: the values in parenthesis are present in percentage.

*Fisher' exact test.

ADC, adenocarcinoma; SCC, squamous cell carcinoma

SCCs exhibited expression of DSC3, while less than $8 \%$ of ADCs were DSC3 positive (table 3 ). This result was also in good agreement with the expression pattern of DSC3 in nonsmall cell lung carcinoma (NSCLC) cell lines, since DSC3 mRNA was only expressed in a SCC cell line H226, while lost in all the ADC cell lines (figure 1A). Compared with the study by Tsuta et al which showed that $100 \%$ of SCC samples were positive for DSC3 staining, our positive rate was lower. The discrepancy is probably due to different antibodies, technologies and the staining evaluation. So far, only p63 and CK5/6 are widely used as diagnostic markers for SCC of lung, while thyroid transcription factor-1 (TTF-1) together with CK7 is considered as a marker for lung $\mathrm{ADC} .^{31-34}$ Based on the expression of DSC3 alone, it might be not sufficient to make a diagnosis for SCC of lung, however, we hope that in combination with the classic markers, DSC3 may contribute to subclassification of NSCLC.

Desmosomal proteins have also been considered as prognostic markers in various cancer types. For example, downregulation of desmoplakin expression provides prognostic information in human oropharyngeal cancer. ${ }^{21}$ Decreased DSG3 expression was associated with poor prognosis in lung cancer. ${ }^{11}$ Recently,

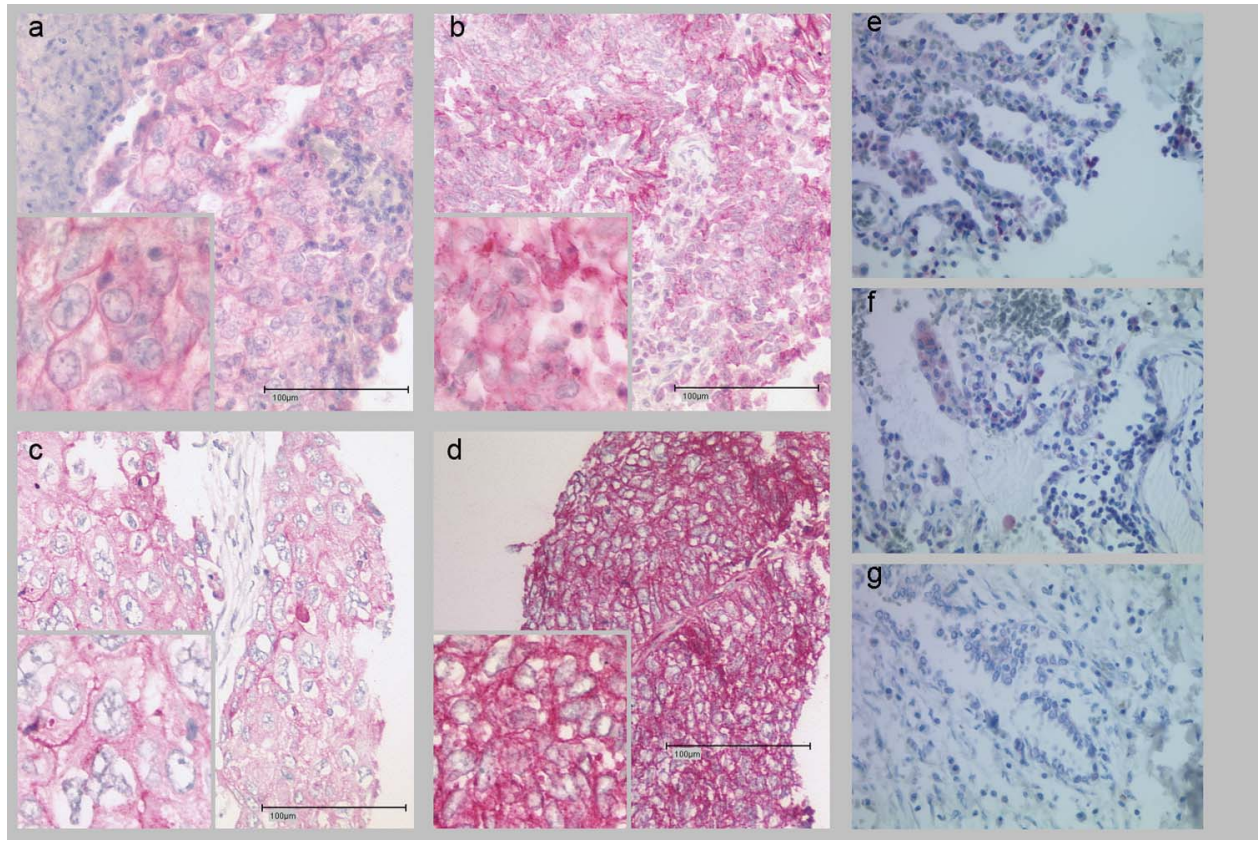

Figure 2 Examples of DSC1-3 protein expression in primary squamous cell carcinoma of lung and bronchial epithelial cells of normal bronchus. DSC1-3 proteins were mainly localised in membrane. A: DSC1 positive staining; B: DSC2 positive staining; C: DSC3 moderately positive; D: DSC3 strongly positive. E-G: DSC1-3 negative staining in normal bronchial epithelial cells. Image with $20 \times$ magnification of the corresponding case is showed in the inset. This figure is only reproduced in colour in the online version. 
a

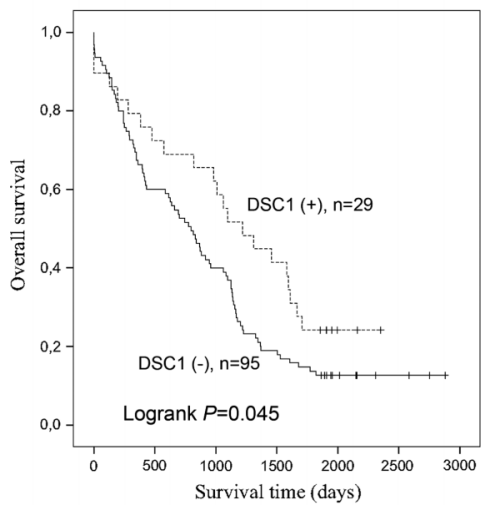

b

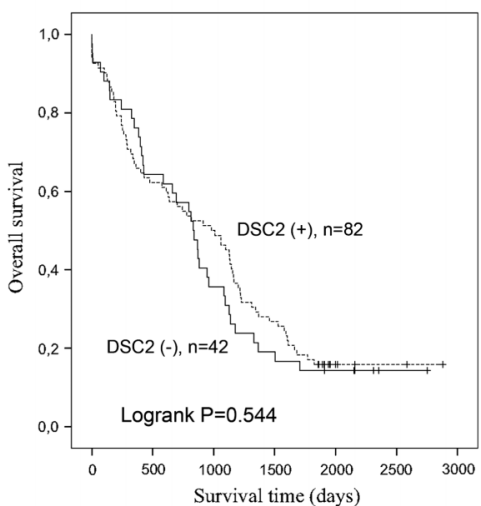

$\mathrm{C}$

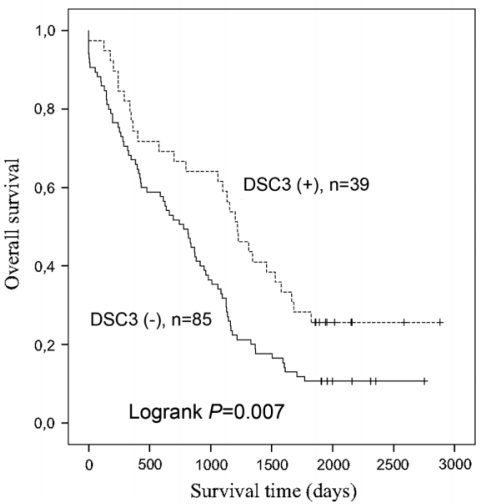

Figure 3 Expression of DSC1 and DSC3 predicted clinical outcome in primary lung cancer. Kaplan Meier curves showed that patients with lower expression of DSC1 or DSC3 had shorter overall survival time compared to patients with higher expression of DSC1 or DSC3 (A, C). In contract, DSC2 expression was not significantly linked to patients' survival (B).

Table 4 Cox hazard analyses of overall survival of lung cancer patients

\begin{tabular}{|c|c|c|c|c|c|}
\hline \multirow[b]{2}{*}{ Variables } & \multirow[b]{2}{*}{ df } & \multirow[b]{2}{*}{ HR } & \multicolumn{2}{|l|}{$95 \% \mathrm{Cl}$} & \multirow[b]{2}{*}{ p Value } \\
\hline & & & Lower & Upper & \\
\hline \multicolumn{6}{|l|}{ DSC1 } \\
\hline $\begin{array}{l}\text { Negative/Positive (95 : 29) } \\
\quad \text { DSC2 }\end{array}$ & 1 & 1.682 & 1.032 & 2.741 & 0.037 \\
\hline $\begin{array}{l}\text { Negative/Positive (42 : 82) } \\
\quad \text { DSC3 }\end{array}$ & 1 & 0.759 & 0.485 & 1.190 & 0.229 \\
\hline Negative/Positive (85 : 39) & 1 & 2.004 & 1.254 & 3.202 & 0.004 \\
\hline
\end{tabular}

we reported that methylation of DSC3 DNA is a prognostic marker in human colorectal cancer. ${ }^{13}$ In this study, we found that reduced expression of DSC1 and DSC3 was associated with an unfavourable prognosis in lung cancer. Like DSG3, DSC1 and 3 seem to be a potential prognostic marker in lung cancer.

In summary, our data showed that DSC1 may be a marker for tumour differentiation, DSC3 protein expression may have diagnostic value for subclassification of NSCLC into SCC and ADC; moreover, patients with reduced DSC1 and DSC3 expression had poor prognosis. Further studies are needed to explore the functional role of DSCs in lung carcinogenesis.

\section{Take home messages}

- Epigenetic regulation is involved in the downregulation of DSC1-3 in lung cancer cells.

- We propose novel diagnostic marker DSC3 in distinguishing lung SCC from adenocarcinoma.

- Additionally, DSC1 and DSC3 were thought to be novel prognostic markers for patients with lung cancer.

Acknowledgements We acknowledge 'Interdisziplinäres Zentrum für Klinische Forschung' (IZKF) Jena for providing promotion's scholarship to T Cui. We are grateful to B Bergholz, M Köhler, and S Bergmann for their excellent technical assistance.

Contributors All authors have participated in the planning, execution, or analysis of the study. I Petersen und Y Chen conceived the experiment; TC and LY performed the experiments; TK, MM, and $\mathrm{OZ}$ analysed the data; LK and AK collected the samples.
TC and YC interpreted data and wrote the manuscript. All authors have approved this manuscript and believe that the manuscript represents honest work.

Funding The work was supported by the Deutsche Krebshilfe (grant no. 108003).

Competing interests None.

Ethics approval The study was performed according to common ethical standards.

Provenance and peer review Not commissioned; externally peer reviewed.

\section{REFERENCES}

1. Holthöfer B, Windoffer R, Troyanovsky S, et al. Structure and function of desmosomes. Int Rev Cytol 2007;264:65-163.

2. Chidgey M, Dawson C. Desmosomes: a role in cancer? Br J Cancer 2007:96:1783-7.

3. Chitaev NA, Troyanovsky SM. Direct $\mathrm{Ca}^{2+}$-dependent heterophilic interaction between desmosomal cadherins, desmoglein and desmocollin, contributes to cell-cell adhesion. J Cell Biol 1997;138:193-201.

4. Marcozzi C, Burdett ID, Buxton RS, et al. Coexpression of both types of desmosomal cadherin and plakoglobin confers strong intercellular adhesion. J Cell Sci 1998;111:495-509.

5. Tselepis C, Chidgey M, North A, et al. Desmosomal adhesion inhibits invasive behavior. Proc Natl Acad Sci USA 1998;95:8064-9.

6. Chun MG, Hanahan D. Genetic deletion of the desmosomal component desmoplakin promotes tumour microinvasion in a mouse model of pancreatic neuroendocrine carcinogenesis. PLoS Genet 2010;6:e1001120.

7. Kolegraff K, Nava P, Helms MN, et al. Loss of desmocollin-2 confers a tumourigenic phenotype to colonic epithelial cells through activation of Akt/ß-catenin signaling. Mol Biol Cell 2011;22:1121-34.

8. Kurzen H, Münzing I, Hartschuh W. Expression of desmosomal proteins in squamous cell carcinomas of the skin. J Cutan Pathol 2003;30:621-30.

9. Chen YJ, Chang JT, Lee L, et al. DSG3 is overexpressed in head neck cancer and is a potential molecular target for inhibition of oncogenesis. Oncogene 2007;26:467-76.

10. Chung CH, Parker JS, Karaca G, et al. Molecular classification of head and neck squamous cell carcinomas using patterns of gene expression. Cancer Cell 2004:5:489-500.

11. Fukuoka J, Dracheva T, Shih $\mathrm{JH}$, et al. Desmoglein 3 as a prognostic factor in lung cancer. Hum Pathol 2007:8:276-83.

12. Chen J, O'Shea C, Fitzpatrick JE, et al. Loss of desmocollin 3 in skin tumour development and progression. Mol Carcinog 2012;51:535-45.

13. Cui T, Chen Y, Yang L, et al. DSC3 expression is regulated by p53, and methylation of DSC3 DNA is a prognostic marker in human colorectal cancer. $\mathrm{Br} J$ Cancer 2011:104:1013-19.

14. Oshiro MM, Kim CJ, Wozniak RJ, et al. Epigenetic silencing of DSC3 is a common event in human breast cancer. Breast Cancer Res 2005;7:669-80.

15. Difilippantonio S, Chen Y, Pietas A, et al. Gene expression profiles in human non-small and small-cell lung cancers. Eur J Cancer 2003;39:1936-47.

16. Sobin LH, Gospodarowicz MK, Wittekind CH. TNM Classification of Malignant tumours. 2010;138-47.

17. Chen $\mathbf{Y}$, Knösel T, Kristiansen G, et al. Loss of PDCD4 expression in human lung cancer correlates with tumour progression and prognosis. J Pathol 2003; 200:640-6. 
18. Getsios S, Huen AC, Green KJ. Working out the strength and flexibility of desmosomes. Nat Rev Mol Cell Biol 2004;5:271-81.

19. Alazawi WO, Morris LS, Stanley MA, et al. Altered expression of desmosomal components in high-grade squamous intraepithelial lesions of the cervix. Virchows Arch 2003:443:51-6.

20. Breuninger S, Reidenbach S, Sauer CG, et al. Desmosomal plakophilins in the prostate and prostatic adenocarcinomas: implications for diagnosis and tumour progression. Am J Pathol 2010;176:2509-19.

21. Papagerakis S, Shabana AH, Pollock BH, et al. Altered desmoplakin expression at transcriptional and protein levels provides prognostic information in human oropharyngeal cancer. Hum Pathol 2009;40:1320-9.

22. Yashiro M, Nishioka N, Hirakawa K. Decreased expression of the adhesion molecule desmoglein-2 is associated with diffuse-type gastric carcinoma. Eur $J$ Cancer 2006; 42:2397-403.

23. Nei H, Saito T, Tobioka H, et al. Expression of component desmosomal proteins in uterine endometrial carcinoma and their relation to cellular differentiation. Cancer 1996; 78:461-70

24. Monica V, Ceppi P, Righi L, et al. Desmocollin-3: a new marker of squamous differentiation in undifferentiated large-cell carcinoma of the lung. Mod Pathol 2009;22:709-17.

25. Tsuta K, Tanabe Y, Yoshida A, et al. Utility of 10 immunohistochemical markers including novel markers (desmocollin-3, glypican 3, S100A2, S100A7, and Sox-2) for differential diagnosis of squamous cell carcinoma from adenocarcinoma of the Lung. $J$ Thorac Oncol 2011;6:1190-9.
26. Renouf DJ, Wood-Baker R, lonescu DN, et al. BCL-2 expression is prognostic for improved survival in non-small cell lung cancer. J Thorac Oncol 2009;4:486-91.

27. Hirsch FR, Spreafico A, Novello $S$, et al. The prognostic and predictive role of histology in advanced non-small cell lung cancer: a literature review. J Thorac Oncol 2008;3:1468-81.

28. Carney DN. Lung cancer-time to move on from chemotherapy. N Engl J Med 2000;346:126-8.

29. Chute JP, Chen T, Feigal E, et al. Twenty years of phase III trials for patients with extensive-stage small-cell lung cancer: perceptible progress. J Clin Oncol 1999;17:1794-801.

30. Boelens MC, van den Berg A, Vogelzang I, et al. Differential expression and distribution of epithelial adhesion molecules in non-small cell lung cancer and normal bronchus. J Clin Pathol 2007:60:608-14.

31. Chu PG, Weiss LM. Keratin expression in human tissues and neoplasms. Histopathology 2002;40:403-39.

32. Kargi A, Gurel D, Tuna B. The diagnostic value of ttf-1, ck 5/6, and p63 immunostaining in classification of lung carcinomas. Appl Immunohistochem Mol Morphol 2007:15:415-20.

33. Nicholson AG, Gonzalez D, Shah P, et al. Refining the diagnosis and egfr status of non-small cell lung carcinoma in biopsy and cytologic material, using a panel of mucin staining, ttf-1, cytokeratin $5 / 6$, and p63, and egfr mutation analysis. J Thorac Oncol 2010;5:436-41.

34. Terry J, Leung S, Laskin J, et al. Optimal immunohistochemical markers for distinguishing lung adenocarcinomas from squamous cell carcinomas in small tumour samples. Am J Surg Pathol 2010;34:1805-11. 


\section{DP Diagnostic and prognostic impact of desmocollins in human lung cancer}

Tiantian Cui, Yuan Chen, Linlin Yang, et al.

J Clin Pathol 2012 65: 1100-1106 originally published online September 21,2012

doi: 10.1136/jclinpath-2011-200630

Updated information and services can be found at:

http://jcp.bmj.com/content/65/12/1100.full.html

These include:

Data Supplement "Web Only Data"

http://jcp.bmj.com/content/suppl/2012/09/19/jclinpath-2011-200630.DC1.html

References This article cites 33 articles, 6 of which can be accessed free at: http://jcp.bmj.com/content/65/12/1100.full.html\#ref-list-1

Email alerting Receive free email alerts when new articles cite this article. Sign up in service the box at the top right corner of the online article.

Topic Articles on similar topics can be found in the following collections Collections

Lung cancer (oncology) (108 articles)

Lung cancer (respiratory medicine) (108 articles)

Molecular genetics (305 articles)

Notes

To request permissions go to:

http://group.bmj.com/group/rights-licensing/permissions

To order reprints go to:

http://journals.bmj.com/cgi/reprintform

To subscribe to BMJ go to:

http://group.bmj.com/subscribe/ 